\title{
TEMPORAL CHANGES IN CONCENTRATION OF PM10 DUST IN POZNAŃ, MIDDLE-WEST POLAND AS DEPENDENT ON METEOROLOGICAL CONDITIONS
}

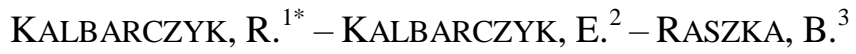 \\ ${ }^{1}$ Institute of Landscape Architecture, Wroctaw University of Environmental and Life Sciences \\ Grunwaldzka St. 55, 50-357 Wroclaw, Poland \\ (phone: +48-71-320-1858; fax: +48-71-320-1863) \\ ${ }^{2}$ Department of Spatial Econometrics, Adam Mickiewicz University in Poznań \\ Krygowskiego St. 10, 61-680 Poznań, Poland \\ (phone: +48-61-829-6309; fax: +48-61-829-6127) \\ ${ }^{3}$ Department of Spatial Management, Wrockaw University of Environmental and Life Sciences \\ Grunwaldzka St. 55, 50-357 Wroclaw, Poland \\ (phone: +48-71-320-5677) \\ *Corresponding author \\ e-mail: robert.kalbarczyk@upwr.edu.pl \\ (Received $15^{\text {th }}$ Dec 2017; accepted $13^{\text {th }}$ Mar 2018)
}

\begin{abstract}
The present analysis is based on hourly data of suspended dust PM10 and meteorological conditions. The aim of the study was to determine the time structure of PM10 concentration and its dependence on meteorological conditions. Hourly data from 2005-2016 were collected from the State Monitoring of Environment situated in Poznań, middle-west Poland. Analysis of the relationship between weather and concentration of PM10 was conducted using the correlation analysis and multiple regression. Time course of PM10 concentration and meteorological elements was characterized not only in the entire 2005-2016 time period but also in its successive years - in daily, monthly and seasonal time steps. In the years 2005-2016, the daily concentration of PM10 significantly depended on meteorological conditions, the strictest dependence being found for wind speed and air temperature. The most frequently recorded, $33 \%$ overall, hourly concentration of PM10 was from within the ranges 10-15 and 15-20 $\mathrm{g} \mathrm{m}^{-3}$. A large, $>90 \mu \mathrm{g} \mathrm{m}^{-3}$, pollution of the atmosphere in the three seasons of the year: winter, spring and autumn was registered mostly between 20 and $4 \mathrm{~h}$. In winter, the large $>90 \mu \mathrm{g} \mathrm{m}^{-3}$, hourly concentrations of suspended PM10 dust, were accompanied by below average values of air temperature, above average relative air humidity, below average wind speeds, from E direction mainly, and above average atmospheric pressure.
\end{abstract}

Keywords: air pollution, bio-climate of town, ecological politics of the state, human health, meteorological conditions

\section{Introduction}

One of the most common air pollutants is an airborne particle of a grain diameter of less than $10 \mu \mathrm{m}$ (PM10). Its prevalence is a consequence of diverse and multiple emission sources. PM10 can be a mixture of organic and inorganic substances, may contain toxic substances, often multi-ring aromatic hydrocarbons, heavy metals, and also dioxins and furanes (Chwil et al., 2015; Emmanouil et al., 2017; Flores et al., 2017; Tasić et al., 2017; Cesari et al., 2018). The anthropogenic dust pollutants come mainly from combustion of fuel to derive energy and from technological processes conducted in industrial plants, and also from transport, mostly road traffic. Atmospheric dust 
comes also from fires or volcanic and seismic activity (Kiesewetter et al., 2013; Gliniak et al., 2015).

Particles with a diameter less than $10 \mu \mathrm{m}$ (PM10), enters the human organism by way of respiratory pathways or indirectly through the digestive tract, when polluted food is consumed (Gładka and Zatoński, 2016; Chiang et al., 2017). Suspended dust is adsorbed in upper stretches of the respiratory tract, whence it is expelled or is accumulated, or permeates into the lungs (D'Amato et al., 2010). The elders, children or the respiratory and circulatory duct sufferers are especially exposed to the negative interaction with the dusts (Badyda et al., 2016; Maji et al., 2017; Pannullo et al., 2017; Sosa et al., 2017; Yang et al., 2017). According to WHO there is convincing evidence that dust in the air, irrespective of its source, has detrimental effect on human health (World Health Organization, 2013).

As reported by the Government Inspectorate (NIK's Report, 2014), air pollution in Poland is the cause of 45,000 early deaths. For example, an inhabitant of a large Polish town (at least $0.5 \mathrm{mln}$ ) lives two and a half years less, on average. It should, however, be emphasized that estimation of the influence of suspended dust in the atmosphere on human health still remains very difficult and imperfect (Gustafsson et al., 2014; Segersson et al., 2017).

In the Poznań agglomeration, the daily norm of PM10 dust, $50 \mu \mathrm{g} \mathrm{m} \mathrm{m}^{-3}$ acc. to Polish regulations, was surpassed in 42 days in 2013 on average, and in 48 days in 2016, mostly in the winter season. Poland, in recent years, was infamously 2nd or 3rd among the EU nations in regard of potential exposure of its city inhabitants to the suspended PM10 dust pollution (NIK's Report, 2014). In Poland, the informing and alarm levels for PM10 dust are as high as 200 and $300 \mu \mathrm{g} \mathrm{m}^{-3}$, respectively. For example, in Italy and France it is approx. four times less than in Poland, and in Hungary and the Check Republic - approx. 3 times less (Richter and Williams, 1998; Judy-Rezler and Toczko, 2016).

In some large cities of Poland, an ecological program has been introduced in order to diminish air pollution (Resolution no. 3056 of the Great-Poland Voivodship of 29 Dec. 2016). In the ecological programs, a series of actions is stated that aim at protection against air pollution, from planting trees or replacement of coal furnaces to building cycling paths and transition from the wheel transport to public transport. To make the program of air quality improvement adequate to the specifics of a town, information concerning the timely structure of PM10 concentration is needed (Balakrishnaiah et al., 2011; Bielec-Bąkowska et al., 2011; Bigi and Ghermandi, 2016; Redington et al., 2016; Mok et al., 2017), and also its dependence on meteorological conditions (Adamek and Ziernicka-Wojtaszek, 2017; Li et al., 2017; Stafoggia et al., 2017; Tiwari et al., 2017). The aim of the study was to determine the time structure of PM10 concentration and its dependence on meteorological conditions in the fifth biggest Polish city, Poznań.

\section{Material and methods}

\section{Study area}

The initial data from the years 2005-2016 were collected from the Voivodship Inspectorate of Environment Protection called Poznań-Botnik, situated in the middle part of Poznań, in Henryk Dąbrowski street $\left(\lambda=16^{\circ} 52^{\prime} 52^{\prime \prime} \mathrm{E}, \varphi=52^{\circ} 25^{\prime} 08^{\prime \prime} \mathrm{N}\right.$, hs $=89$ $\mathrm{m}$ a.s.1.) (Fig. 1). The immission-meteorological station (its code: WpPoznDabrow) is installed on the grounds of the University Botanic Garden of Adam Mickiewicz 
University, in close proximity to residential and recreational areas. A dominant type of development in the vicinity of the station is low, single-family housing.
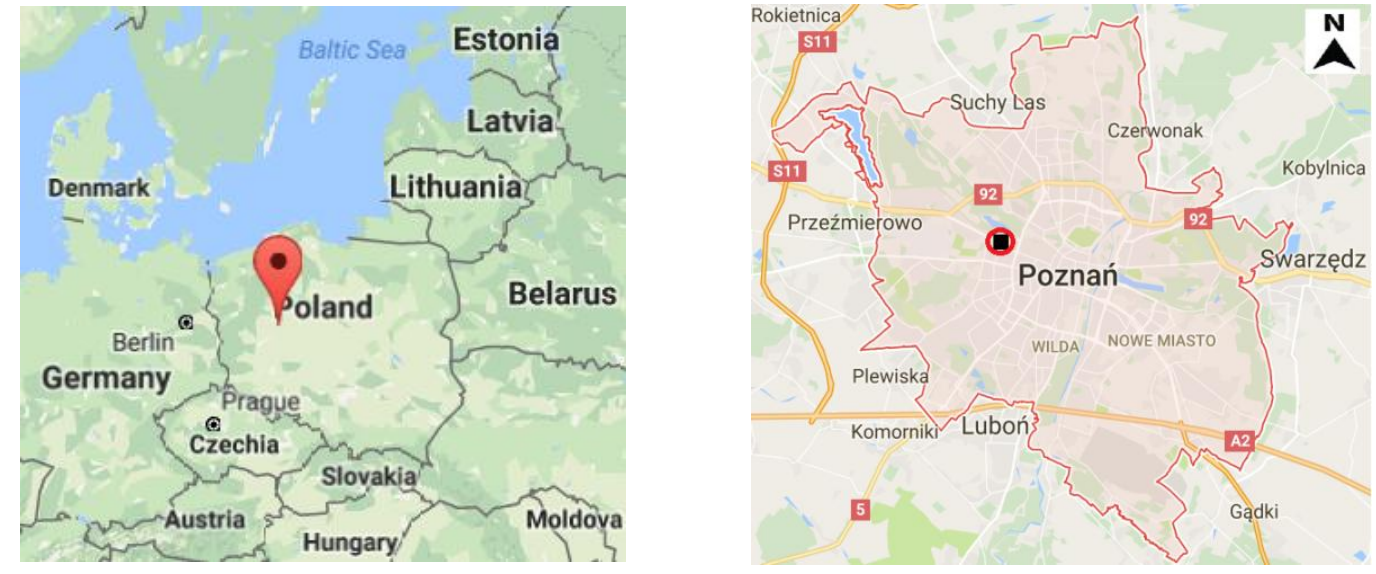

Figure 1. Location of the station of air quality assessment (ם) and of meteorological station (O) in Poznań. Source: https://www.google.pl/(accessed on 04.10.2017)

\section{Material}

The investigation uses hourly data on concentration $\left(\mu \mathrm{g} \mathrm{m}^{-3}\right)$ of PM10 pollution, and also hourly data on meteorological conditions: air temperature $\left(\mathrm{Ta},{ }^{\circ} \mathrm{C}\right)$, relative humidity of the air $(\mathrm{Rh}, \%)$, atmospheric pressure $(\mathrm{Pa}, \mathrm{hPa})$, speed $\left(\mathrm{V}, \mathrm{m} \mathrm{s}^{-1}\right)$ and direction of wind (WD). All parameters, i.e. the concentration of suspended PM10 dust and meteorological elements, describing so-called city background, are measured automatically with analyzers and sensors attested by the Main Inspectorate for Environment Protection.

\section{Methods}

The influence of meteorological conditions on concentration of suspended PM10 dust in the years 2005-2016 was estimated with the use of Pearson's correlation. The analysis of the dependence weather-concentration of PM10 was carried out in successive months of the year (from January to December), and also in the four seasons of year: winter (from December to February), spring (from March to May), summer (from June to August) and in autumn (from September to November). Whereas, evaluation of the collective effect of considered meteorological elements on PM10 immission level was made using the multiple regression method. Assessment of compliance of the model with empirical data was made on the basis of the value of the corrected determination coefficient $\left(\mathrm{R}^{2}\right.$ adj, \%), which takes into account the number of independent variables, and the percent difference between standard deviation of PM10 concentration and the standard error of estimation of the multiple regression equation $(\mathrm{Sd}-\mathrm{Sy}, \%)$. The participation of a meteorological element in explaining the value of PM10 immission was determined on the basis of the partial correlation coefficient and $\mathrm{t}-$ Student test. Both in the analysis of correlation and in multiple regression the dependent transformed variable $f(\mathrm{PM} 10)$ was calculated from the formula (Eq. 1):

$$
\mathrm{f}(\mathrm{PM} 10)=\log (\mathrm{PM} 10)
$$


where $P M 10$ signifies concentration of suspended dust particles smaller than $10 \mu \mathrm{m}$.

The structure of occurrence of PM10 concentrations within the assumed intervals has been characterized in the whole multiyear period 2005-2016 both in daily and seasonal time steps. In a similar pattern, as in the case of frequency of occurrence of PM10 concentration, the time course of PM10 concentration and meteorological elements has been described, and additionally monthly analysis in successive years were made.

For the most unfavorable, winter, aero-sanitary conditions in Poznań (in the years 2005-2016) the mean values of meteorological elements were determined. To this end, from the set of all hourly initial data two groups of data were selected on the basis of suspended PM10 dust $-<20 \mu \mathrm{g} \mathrm{m}^{-3}$ and $>90 \mu \mathrm{g} \mathrm{m}^{-3}$. The basis for determination of boundary values, that describe small and large values of PM10 in the air were percentile values, 30 and $90 \%$ respectively, determined on the basis of the entire set of data (ca. 25,000 hourly values). Recorded both for small $\left(<20 \mu \mathrm{g} \mathrm{m}^{-3}\right)$ and large $\left(>90 \mu \mathrm{g} \mathrm{m}^{-3}\right)$ values of PM10 the values of the meteorological elements Ta, Rh, $\mathrm{Pa}, \mathrm{V}$ and WD were calculated for successive hours of $24 \mathrm{~h}$ day and night.

\section{Results and discussion}

\section{Relation between PM10 concentration and meteorological conditions}

The assessment of the relation, conducted in 2005-2016, between daily concentration of PM10 dust, transformed according to the formula (Eq. 1) and analyzed meteorological elements has shown a significant, negative influence of air temperature: in winter $(\mathrm{r}=-0.36, \mathrm{P}<0.01)$, spring $(\mathrm{r}=-0.15, \mathrm{P}<0.01)$ and autumn $(\mathrm{r}=-0.31$, $\mathrm{P}<0.01)$ and significant, positive in summer $(\mathrm{r}=0.49, \mathrm{P}<0.01)($ Table 1$)$.

Table 1. Relation between daily concentration of suspended PM10 dust and meteorological elements. The years 2005-2016

\begin{tabular}{c|c|c|c|c}
\hline \multirow{2}{*}{ Element } & \multicolumn{4}{|c}{ Season of the year } \\
\cline { 2 - 5 } & $\begin{array}{c}\text { Winter } \\
\text { (December-February) } \\
(\mathrm{n}=1034)\end{array}$ & $\begin{array}{c}\text { Spring } \\
\text { (March-May) } \\
(\mathrm{n}=1089)\end{array}$ & $\begin{array}{c}\text { Summer } \\
(J u n e-A u g u s t) \\
(\mathrm{n}=1032)\end{array}$ & $\begin{array}{c}\text { Autumn } \\
\text { (September-November) } \\
(\mathrm{n}=997)\end{array}$ \\
\hline $\mathrm{Ta}\left({ }^{\circ} \mathrm{C}\right)$ & $-0.36^{* * *}$ & $-0.15^{* * *}$ & $0.49 * * *$ & $-0.31 * * *$ \\
$\mathrm{Rh}(\%)$ & $0.08^{* * *}$ & $-0.07 * * *$ & $-0.15 * * *$ & $0.13 * * *$ \\
$\mathrm{~Pa}(\mathrm{hPa})$ & $0.15^{* * *}$ & $0.13 * * *$ & $\mathrm{n} . \mathrm{s}$. & $0.22^{* * *}$ \\
$\mathrm{~V}\left(\mathrm{~m} \mathrm{~s}^{-1}\right)$ & $-0.58^{* * *}$ & $-0.27 * * *$ & $-0.40 * * *$ & $-0.45^{* * *}$ \\
\hline
\end{tabular}

$\mathrm{Ta}$ - air temperature $\left({ }^{\circ} \mathrm{C}\right), \mathrm{Rh}-$ air relative humidity $(\%), \mathrm{Pa}-$ atmospheric pressure $(\mathrm{hPa}), \mathrm{V}-$ wind speed $\left(\mathrm{m} \mathrm{s}^{-1}\right), \mathrm{n}-$ number of samples, $* * *$ significant with $\mathrm{P} \leq 0.01$, n.s. - non significant at $\mathrm{P}<0.1$

In spring-summer season the $\mathrm{Rh}$ index has a significantly negative effect on PM10 concentration. Atmospheric pressure had significant positive effect on the content of suspended PM10 dust in the year, save for summer, the strongest dependence being documented for autumn $(\mathrm{r}=0.22, \mathrm{P}<0.01)$. High pressure is recorded when the radiation cooling of the low air layers occurs and often unstable equilibrium in the atmosphere, including near-ground elevated inversions. The anemometric conditions, described by wind speed, were significantly, negatively correlated with the level of PM10 dust content in all considered seasons of the year. Correlation coefficients calculated for this dependence varied from -0.27 in spring to -0.58 in winter. 
For a full description of the influence of meteorological conditions on concentration of the dust, the relation wheather-PM10 was considered in successive months, hour by hour (Fig. 2). Highest positive values $(\mathrm{r} \geq 0.4)$ of correlation coefficient for the relation Ta-PM10 were found for the May-September period, at 7-11 h; whereas highest negative $(\mathrm{r} \leq-0.4)$ - in January-February at $21-17 \mathrm{~h}$. Air humidity had strongest negative effect on PM10 in the March-September period at 7-11, and strongest positive - in November-December, in night, morning and afternoon hours. Low pressure was accompanied by low concentration of PM10 during April-September at 11-21 h. Wind speed favorably affected air quality, as it is apparent from Table 1. A positive relationship V-PM10 was found in April-May at 17-20 h.
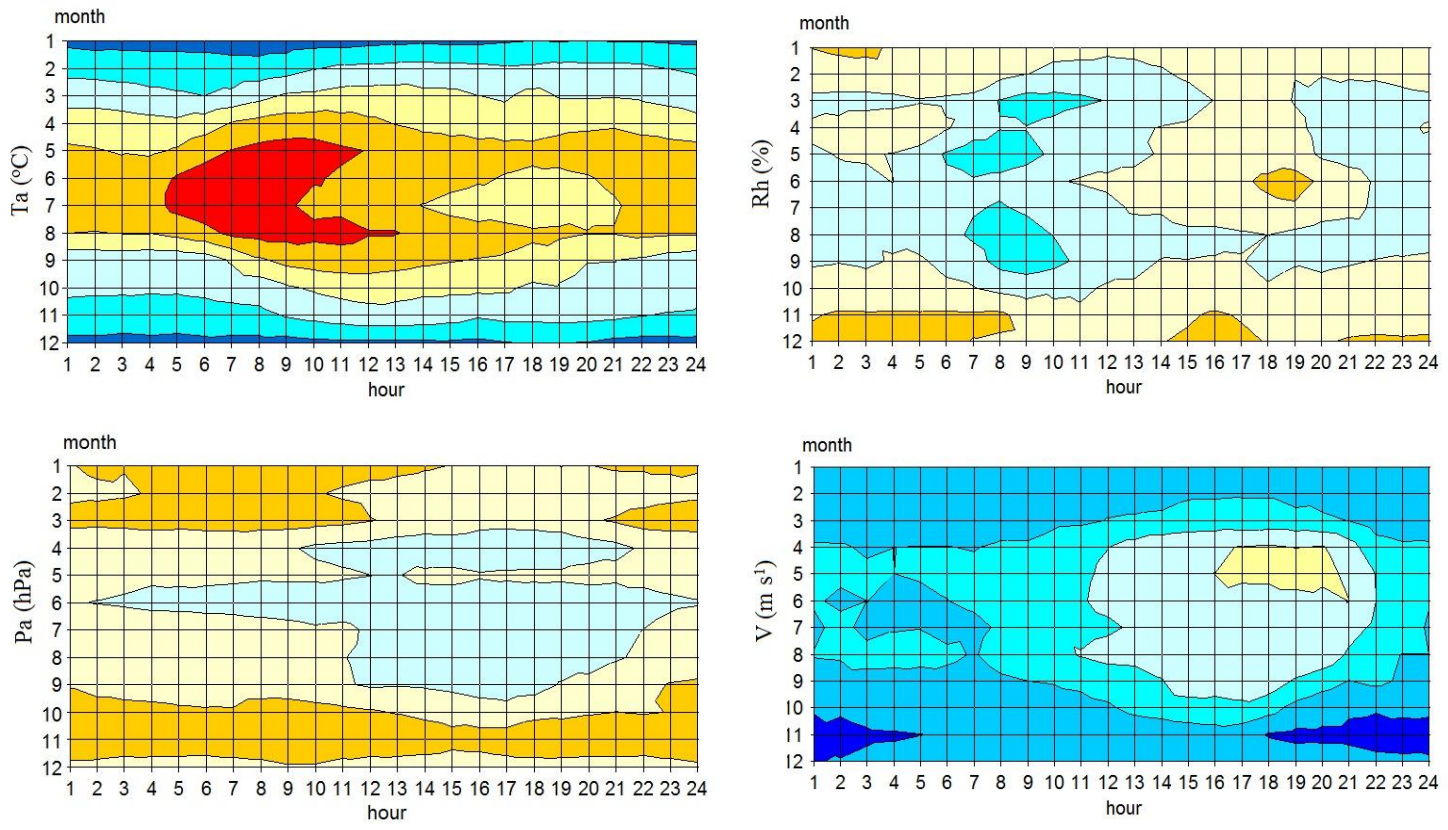

Correlation coefficient $(\mathrm{r})$ :

$-0.6-0.4 \square-0.4--0.2 \square-0.2-0.0 \square 0.0-0.2 \square 0.2-0.4 \square 0.4-0.6$

Figure 2. Monthly distribution of the relations between hourly PM10 concentrations and meteorological elements. The years 2005-2016

Meteorological elements in the system determined the value of PM10 concentration, from ca. 13 to $38 \%$, but mostly in autumn, and then in winter (Table 2).

The strongest influence in all the seasons on air pollution had Ta and V. The partial correlation coefficients calculated for the independent variables in the multiple regression equations varied from -0.18 for winter to 0.404 for summer in the case of Ta and from -0.29 to -0.57 for autumn in the case of $\mathrm{V}$. Aside of the indicators Ta and $\mathrm{V}$, in spring a significant negative effect on PM10 exerted also air humidity, and in summer atmospheric pressure.

\section{Frequency of PM10 occurrence in seasons of the year}

The measured PM10 concentration throughout the year was, most frequently, in the four assumed intervals: $10-15,15-20,20-25$ and $25-30 \mu \mathrm{g} \mathrm{m}^{-3}$, respectively, with the frequencies ca. 16, 17, 14 and 11\% (Fig. 3), respectively. A bit less frequently, ca. 8\%, 
was recorded pollution in the range $30-35 \mu \mathrm{g} \mathrm{m}^{-3}$. Large dust concentration $(>60 \mu \mathrm{g} \mathrm{m}$ ${ }^{3}$ ) was infrequent $(<2 \%)$.

Table 2. Assessment of the combined effect of meteorological conditions on daily concentration of PM10 dust. The years 2005-2016

\begin{tabular}{|c|c|c|c|c|c|c|c|}
\hline \multirow{2}{*}{$\begin{array}{l}\text { Season of the } \\
\text { year }\end{array}$} & \multicolumn{4}{|c|}{$\begin{array}{c}\text { Coefficients of partial correlation of multiple } \\
\text { regression }\end{array}$} & \multirow[t]{2}{*}{$\mathbf{n}$} & \multicolumn{2}{|c|}{$\begin{array}{l}\text { Evaluation of the } \\
\text { equation quality }\end{array}$} \\
\hline & $\mathrm{Ta}\left({ }^{\circ} \mathrm{C}\right)$ & Rh (\%) & Pa (hPa) & $\mathrm{V}\left(\mathrm{m} \mathrm{s}^{-1}\right)$ & & $\mathbf{R}_{\text {adj. }}^{2}$ & Sd-Sy (\%) \\
\hline $\begin{array}{c}\text { Winter } \\
\text { (December- } \\
\text { February) }\end{array}$ & $\begin{array}{c}-0.18 \\
(-6.84)^{*}\end{array}$ & & & $\begin{array}{c}-0.51 \\
(-19.35)\end{array}$ & 1034 & 36.5 & 23.6 \\
\hline $\begin{array}{c}\text { Spring } \\
\text { (March-May) }\end{array}$ & $\begin{array}{c}-0.26 \\
(-8.36)\end{array}$ & $\begin{array}{l}-0.097 \\
(-3.17)\end{array}$ & & $\begin{array}{c}-0.309 \\
(-10.608)\end{array}$ & 1089 & 13.1 & 11.2 \\
\hline $\begin{array}{c}\text { Summer } \\
\text { (June-August) }\end{array}$ & $\begin{array}{c}0.404 \\
(14.48) \\
\end{array}$ & & $\begin{array}{c}-0.18 \\
(-6.62) \\
\end{array}$ & $\begin{array}{c}-0.29 \\
(-10.304) \\
\end{array}$ & 1032 & 31.8 & 17.7 \\
\hline $\begin{array}{c}\text { Autumn } \\
\text { (September- } \\
\text { November) }\end{array}$ & $\begin{array}{c}-0.34 \\
(-13.38)\end{array}$ & & & $\begin{array}{c}-0.57 \\
(-22.45)\end{array}$ & 997 & 37.8 & 22.2 \\
\hline
\end{tabular}

*In brackets are given values of t-Student's test at significance level $\mathrm{P}<0.01, \mathrm{R}_{\text {adj }}^{2}$ - adjusted determination coefficient (\%), Sd-Sy (\%) - percent difference between standard deviation of PM10 concentration and standard deviation in estimation of the multiple regression equation. Other explanations, see Table 1

The frequency of particular PM10 dust size occurrence in respective seasons of the year was not always the same as in the scale of the entire year. In winter, the largest dust pollution was in the two intervals - 15-20 and 20-25 $\mu \mathrm{g} \mathrm{m}^{-3}$, with similar frequency of ca. $11 \%$. In autumn, as throughout the year, PM10 concentration was most often from 10 to $30 \mu \mathrm{g} \mathrm{m}^{-3}$. A similar distribution of frequency was for the warmer seasons of the year. In spring, in the four successive intervals from 10 to $30 \mu \mathrm{g} \mathrm{m}^{-3}$, concentration of particles less than $10 \mu \mathrm{m}$ occurred at almost $60 \%$ frequency in total, and in summer it was $85 \%$. In all the seasons, a small $\left(<5 \mu \mathrm{g} \mathrm{m}^{-3}\right)$ concentration of the pollution was rarely recorded, at frequency varying from $0.1 \%$ in summer to $1.8 \%$ in winter. In summer, there was not a result of PM10 concentration greater than $55 \mu \mathrm{g} \mathrm{m}{ }^{-3}$.

The frequency of a certain size of PM10 in the respective seasons depended on time of the day and night (Fig. 3). In winter, the air pollution in the range $0-10 \mu \mathrm{g} \mathrm{m}^{-3}$ was most often from 11 to $14 \%$, recorded at $3-10 \mathrm{~h}$; whereas in the range $10-20 \mu \mathrm{g} \mathrm{m}^{-3}$ it was $20 \%$ frequent at $4-16 \mathrm{~h}$. In the successive ranges, from 20 to $80 \mu \mathrm{g} \mathrm{m} \mathrm{m}^{-3}$, dust concentration did not exhibit a marked daily variation. Large (90-100 and $>100 \mu \mathrm{g} \mathrm{m}^{-3}$ ) dust concentrations were most frequently recorded in evening and night hours. Smallest dust concentrations in spring and summer $\left(0-10 \mu \mathrm{g} \mathrm{m}^{-3}\right)$ were recorded mostly at $12-$ $19 \mathrm{~h}$, and in the range $10-20 \mu \mathrm{g} \mathrm{m}^{-3}$ at 11-18 $\mathrm{h}$. In the two seasons the PM10 $>50 \mu \mathrm{g} \mathrm{m}^{-3}$ was most frequent in late afternoon and night hours. In summer, the concentration was small $\left(<10 \mu \mathrm{g} \mathrm{m}^{-3}\right)$ and $>20 \%$ frequent at $10-20 \mathrm{~h}$, and a medium one $\left(>50 \mu \mathrm{g} \mathrm{m}^{-3}\right)$ at $22-3 \mathrm{~h}$.

\section{Variation of PM10 concentration and meteorological elements}

The content of PM10 in the air exhibited seasonal variation (Fig. 4). The annual variation of PM10 was around $31.5 \mu \mathrm{g} \mathrm{m}^{-3}$. In Poznań, in 2005-2016, the concentration 
in winter $\left(42.4 \mu \mathrm{g} \mathrm{m}^{-3}\right)$ was over two times greater than in summer $\left(18.8 \mu \mathrm{g} \mathrm{m}^{-3}\right)$, in autumn a little higher (by $4.1 \mu \mathrm{g} \mathrm{m}^{-3}$ ) than in spring. The highest, over $40 \mu \mathrm{g} \mathrm{m}^{-3}$, mean concentration of the pollution was recorded in November-March period, and it varied from $40 \mu \mathrm{g} \mathrm{m}^{-3}$ in December to ca. $46 \mu \mathrm{g} \mathrm{m} \mathrm{m}^{-3}$ in February. The highest, amounting to $39.1 \mu \mathrm{g} \mathrm{m}{ }^{-3}$, annual PM10 concentration occurred in 2011 , and the lowest $\left(27.8 \mu \mathrm{g} \mathrm{m}^{-3}\right)$ - in 2007. However, in individual months, the highest concentrations of the pollution were in different years; for instance, in January 2010, February 2012, June 2008 and August 2015.

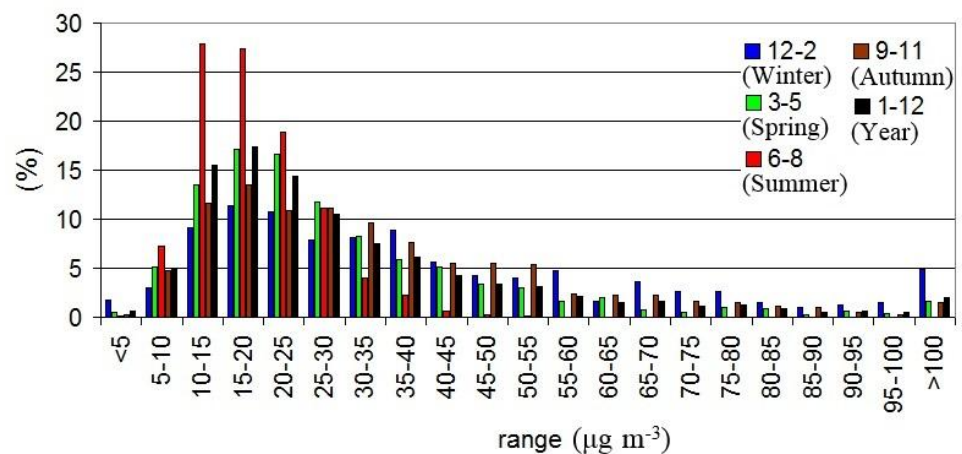

Winter

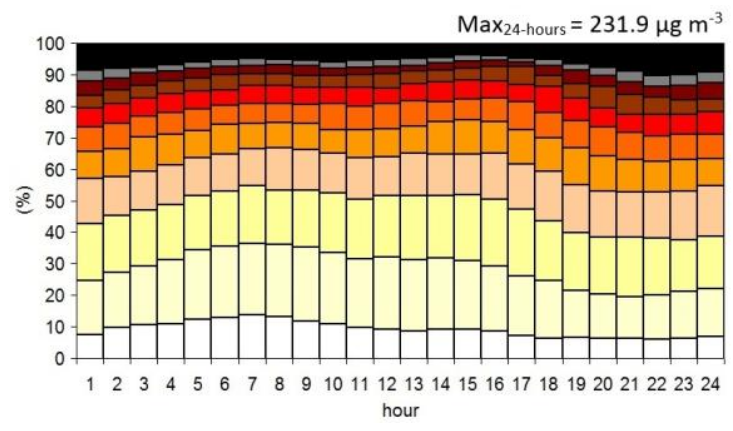

Summer

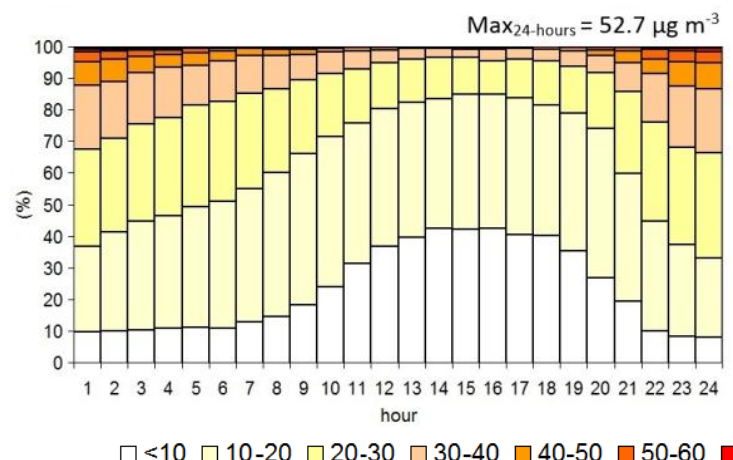

Spring

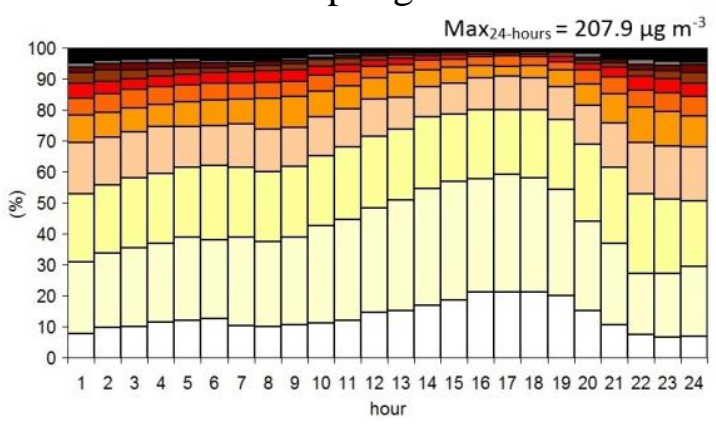

Autumn

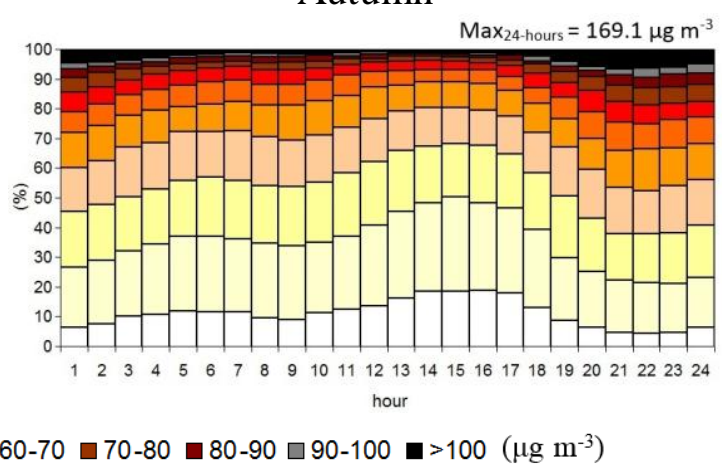

Figure 3. Frequency of occurrence of hourly PM10 concentration in the multiple-year period 2005-2016

The air temperature in the multiple-year period, in annual scale was $9.1^{\circ} \mathrm{C}$, and varied depending on month from $-1.5^{\circ} \mathrm{C}$ in January to $19.8^{\circ} \mathrm{C}$ in July (Fig. 4), being a little lower (by $0.2^{\circ} \mathrm{C}$ ) from spring to autumn. In the successive years of the period the summers were found to be warmer and warmer, especially in July-August, and also winter. For example, in January $2006 \mathrm{Ta}$ was only $-7.5^{\circ} \mathrm{C}$, and in January 2015 it was 
even $2.5^{\circ} \mathrm{C}$. The monthly course of Rh was a reverse of Ta. Such highest mean relative humidity of the air was recorded in December (93.0\%), and then in November $(92.3 \%)$. In months of the best air quality with respect to dustiness, i.e. in May-July, the Rh varied around ca. $70 \%$. The most wet year, of the considered ones, was 2010 when Rh varied from 74.8 to $93.6 \%$ in winter. Unlike $\mathrm{Ta}$ and $\mathrm{Rh}$, the atmospheric pressure showed a reversed time course, the highest $\mathrm{Pa}$ was in October $(1007.5 \mathrm{hPa})$, and then in December $(1006.3 \mathrm{hPa})$ and in September $(1006.2 \mathrm{hPa})$. The mean multi-year values of the indicator $\mathrm{Pa}$ was $1005.1 \mathrm{hPa}$ and varied from $1002.7 \mathrm{hPa}$ in 2010 to $1009.0 \mathrm{hPa}$ in 2005.
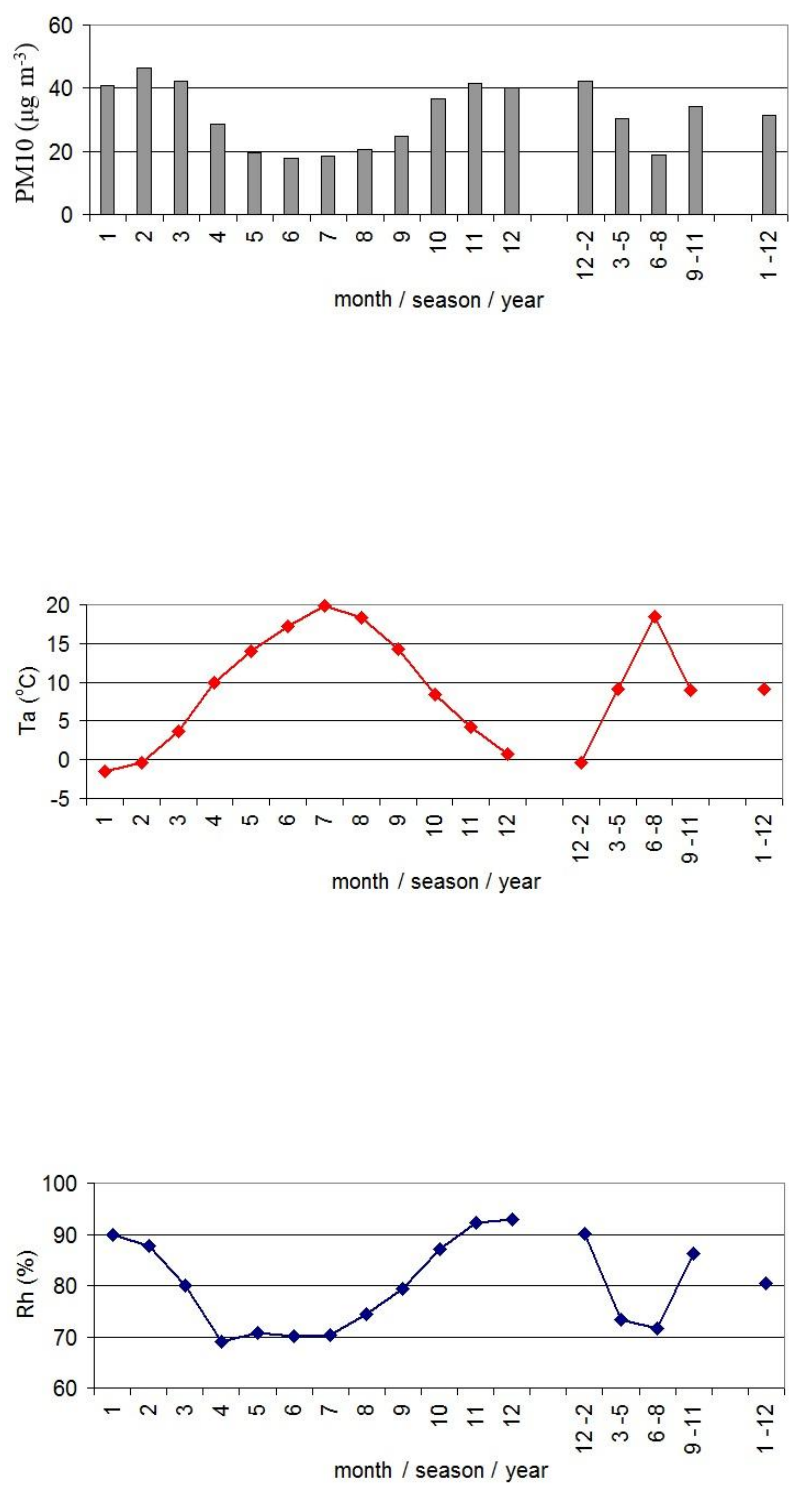
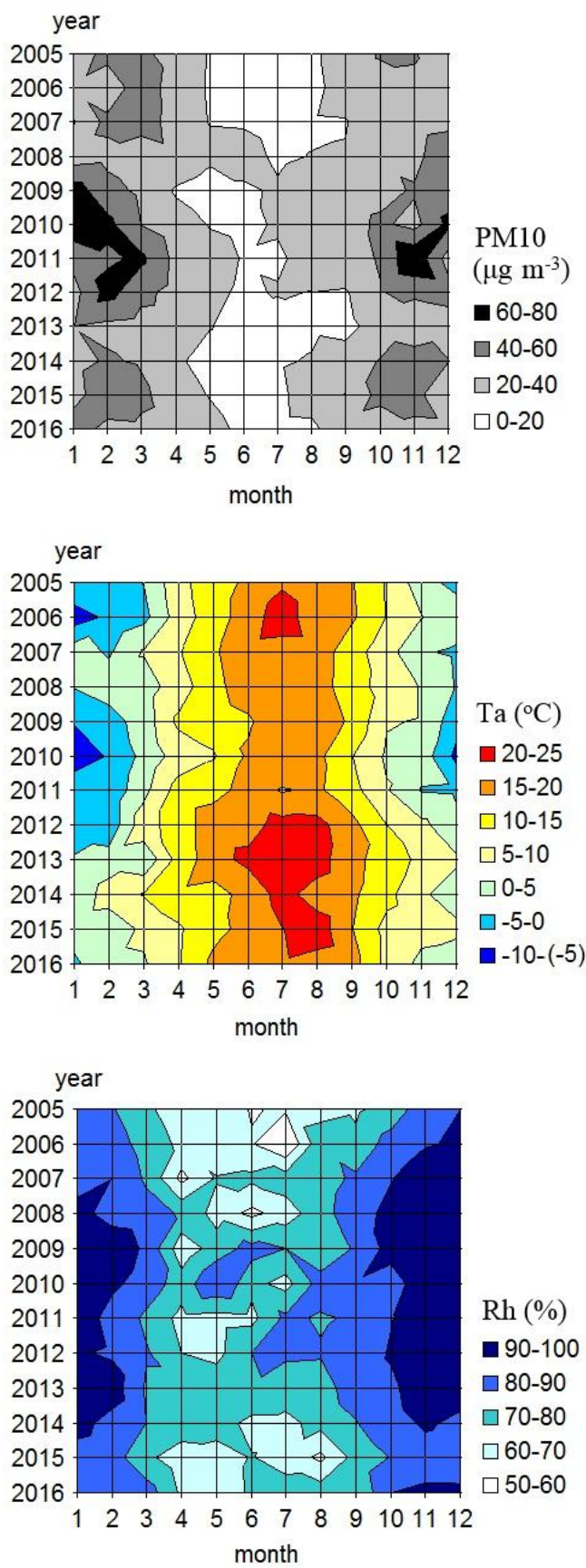

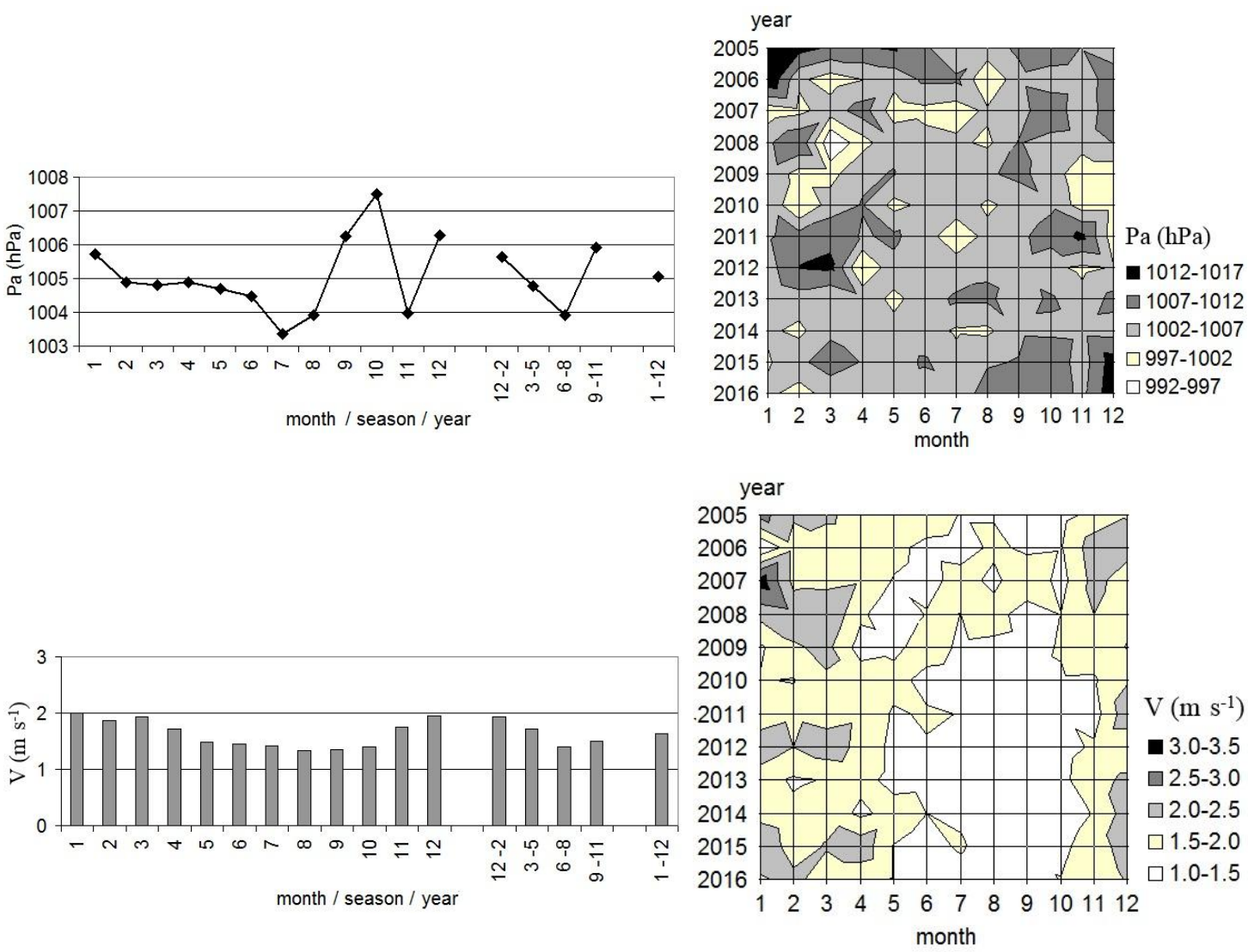

Figure 4. Course of occurrence of PMIO concentration and meteorological elements in the multiple-year period 2005-2016, and by the years

In turn, wind speed, which strongly determined PM10 content in all considered seasons, varied from $1.3 \mathrm{~m} \mathrm{~s}^{-1}$ in August and September to $2.0 \mathrm{~m} \mathrm{~s}^{-1}$ in January and December of 2005-2016. In spring wind speed was, on average, by $0.2 \mathrm{~m} \mathrm{~s}^{-1}$ greater than in autumn, i.e. inversely than PM10 concentration. It blew the strongest in 2007, when the mean monthly $\mathrm{V}$ was from $1.3 \mathrm{~m} \mathrm{~s}^{-1}$ in June to even $3.2 \mathrm{~m} \mathrm{~s}^{-1}$ in January.

At the measurement point, in 2005-2016, the wind was most often from SW (18.8\%), and then from $\mathrm{W}(16.2 \%)$ (Fig. 5). Most infrequent was the wind from $\mathrm{N}$ and NE, 3.7 and $5.0 \%$, respectively. In the 12 -year period, windless weather was at $5.2 \%$ frequency. The content of suspended dust exhibited not only annual but also daily changes (Fig. 6). The highest, $\geq 50 \mu \mathrm{g} \mathrm{m}^{-3}$, PM10 concentration in 2005-2016 was recorded in the months of February and March at 21-2 h, and in November at 20-24 h. Dustiness was lowest in the period May - August at 10-20 h, and in June-July even from 6 or $7 \mathrm{~h}$. When dustiness was highest, the air temperature varied, on average, from -5 to $5^{\circ} \mathrm{C}$ (Fig. 6). Small dust content was recorded when Ta was from 15 to $25^{\circ} \mathrm{C}$, mostly at $9-20 \mathrm{~h}$. The time course of Rh, like that of PM10 and Ta, was close to the latitudinal one. In the study period, the content of water vapour in the air was greatest in autumn and winter months at 18-9 h, in January and February only from $21 \mathrm{~h}$. In the case of atmospheric pressure the time course was less variable. The highest $\mathrm{Pa}$, varying from 1006 to $1008 \mathrm{hPa}$, occurred mostly in September-October during day and night, and in December, apart from 13-15 h. 


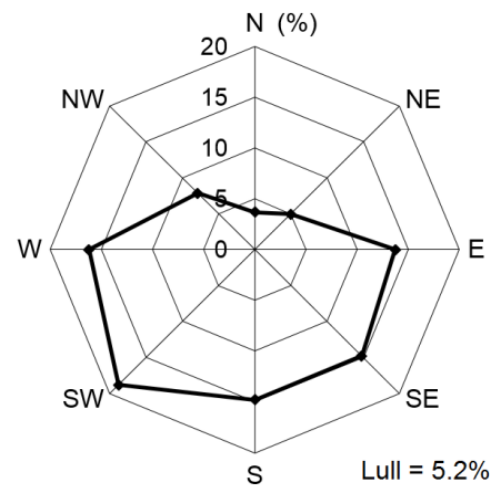

Figure 5. Annual wind directions, constructed on the basis of hourly data. The years 2005-2016
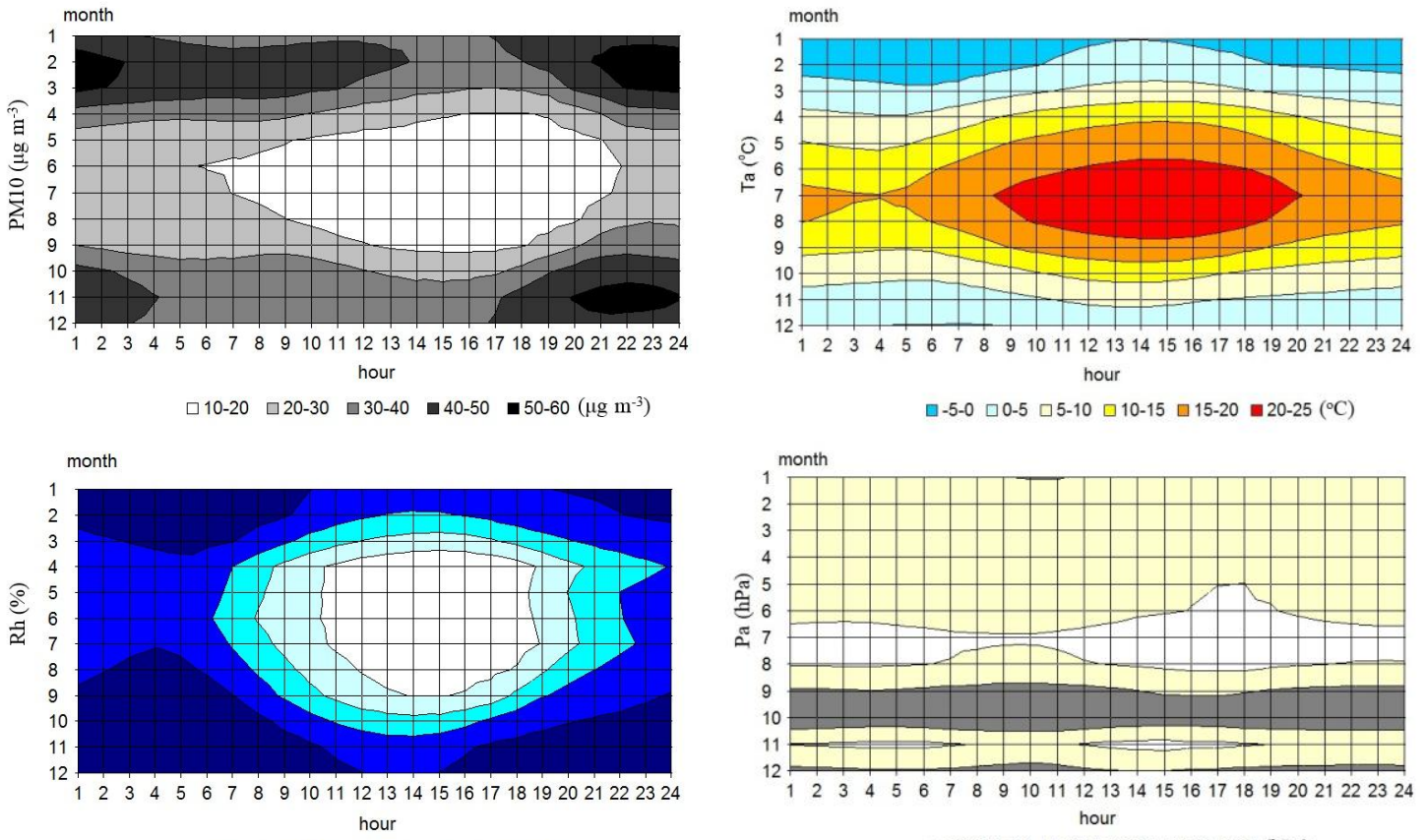

$\square-5-0 \square 0-5 \square 5-10 \square 10-15 \square 15-20=20-25\left({ }^{\circ} \mathrm{C}\right)$

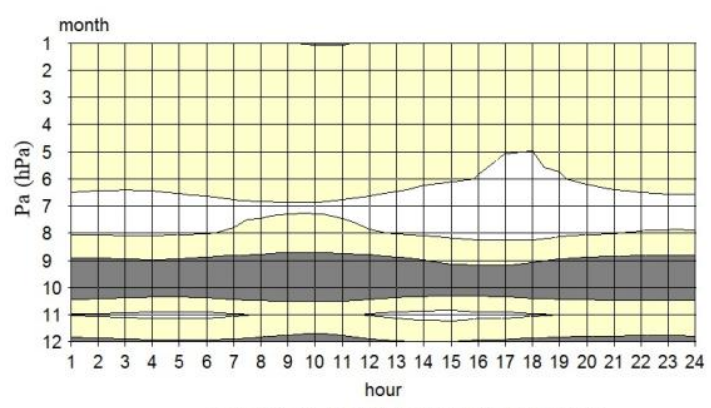

$\square 50-60 \square 60-70 \square 70-80 \square 80-90 \square 90-100(\%)$

口1002-1004 口1004-1006 घ1006-1008 (hPa)

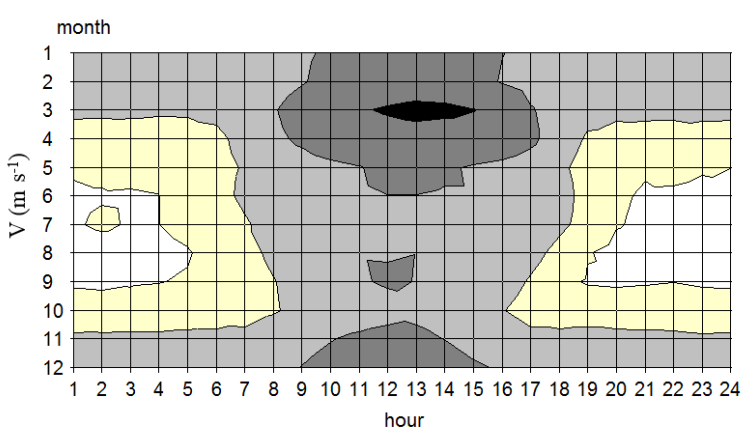

$\square 0.5-1.0 \square 1.0-1.5 \square 1.5-2.0 \square 2.0-2.5 \square 2.5-3.0\left(\mathrm{~m} \mathrm{~s}^{-1}\right)$

Figure 6. Timely structure of PM10 concentration and meteorological elements hour by hour in the analyzed period of 2005-2016

$\mathrm{Pa}$ in the range 1002-1004 $\mathrm{hPa}$ was most pronounced in the period June-August and in November, being so in June at 16-19 h, in July in day and night, in August at 13-21 h 
and 1-6 h, in November at 1-7 $\mathrm{h}$ and 12-18 h. However, wind speed clearly depended not only on month but also on the hour. In the period 2005-2016, it blew the strongest (from 2.0 to $3.0 \mathrm{~m} \mathrm{~s}^{-1}$ ) in January-April at 9-16 $\mathrm{h}$ and in November-December at 10$14 \mathrm{~h}$; and the weakest, $\leq 1 \mathrm{~m} \mathrm{~s}^{-1}$, it blew in June-September at 20-4 h.

In the years 2005-2016 (from December to February), small, $\leq 20 \mu \mathrm{g} \mathrm{m} \mathrm{m}^{-3}$, concentration of PM10 was not much differentiated in successive hours of the day, and varied from $11.8 \mu \mathrm{g} \mathrm{m}^{-3}$ at $7 \mathrm{~h}$ to $13.0 \mu \mathrm{g} \mathrm{m}^{-3}$ at $17 \mathrm{~h}$ (Fig. 7). A higher than average, $\geq 12.6 \mu \mathrm{g} \mathrm{m}^{-3}$, small PM10 concentration was calculated for 10-1 h. In winter, an opposite time course was found for large, $\geq 90 \mu \mathrm{g} \mathrm{m} \mathrm{m}^{-3}$, dust concentration; above average $\left(\geq 123.6 \mu \mathrm{g} \mathrm{m}^{-3}\right)$ for $22-9 \mathrm{~h}$. Small, hourly concentrations of the analyzed dust pollution were accompanied by higher air temperatures - from 1.2 to $3.3^{\circ} \mathrm{C}$, and large ones - by lower temperature from -7.8 to $-3.5^{\circ} \mathrm{C}$, which is according to the relations TaPM10 (Table 1).
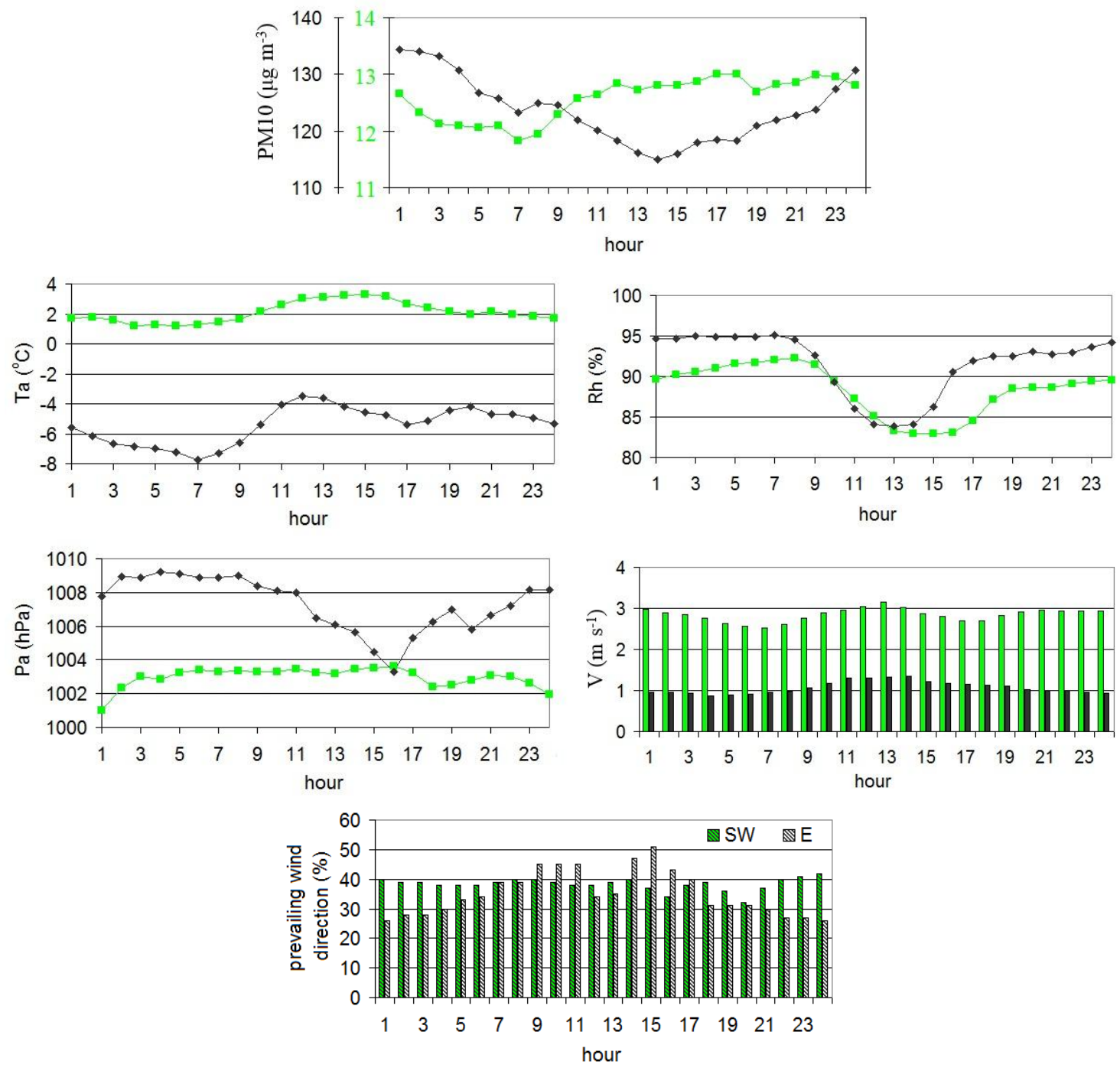

$-<20 \mu \mathrm{g} \mathrm{m}^{-3} \bullet->90 \mu \mathrm{g} \mathrm{m}^{-3}$

Figure 7. Winter, hourly concentrations of suspended PM10 dust, small $\left(<20 \mu \mathrm{g} \mathrm{m}^{-3}\right)$ and large ( $\left.>90 \mu \mathrm{g} \mathrm{m}^{-3}\right)$, together with meteorological conditions. The years 2005-2016 


\section{Small and large PM10 concentrations and accompanying meteorological conditions}

Small dust content was accompanied by above-average wind speed, whose daily variation was from 2.5 to $3.2 \mathrm{~m} \mathrm{~s}^{-1}$, the strongest wind being from 11 to $14 \mathrm{~h}$. Clean air was recorded at the station when the wind was from SW, blowing at a frequency of 32 to $42 \%$. In turn, lower than average values of $\mathrm{Rh}$ and $\mathrm{Pa}$ induced small dust concentrations. The Rh, varying from ca. 84 to $91 \%$, were accompanied by both small and large PM10 concentrations. Unfavorable aero-sanitary conditions in DecemberFebruary, when PM10 $\geq 90 \mu \mathrm{g} \mathrm{m}^{-3}$, were recorded in the study period under the daily meteorological conditions: $\mathrm{Ta}-$ from -7.8 to $-3.5^{\circ} \mathrm{C}, \mathrm{Rh}-$ from 84 to $95 \%, \mathrm{~Pa}-$ from 1003.3 to $1009.2 \mathrm{hPa}, \mathrm{V}$ - from 0.9 to $1.3 \mathrm{~m} \mathrm{~s}^{-1}$ and wind mainly from 26 to even $51 \%$ from the $\mathrm{E}$ direction. The wind was most often from $\mathrm{E}$ at 9-11 and 14-17.

\section{Discussion}

The work has proved that PM10 concentration in Poznan increased in the periods of a temperature drop in winter, autumn and spring but also during an increase in temperature in summer. The deterioration of air quality in the autumn-winter and spring period might be connected with an increased intensity of burning solid, conventional fuels and biomass in the Poznan heat and power plants, and also in individual heating installations, in which, regrettably, also municipal waste is burned (Ćwiek and Majewski, 2015). High concentration of PM10 dust in the summer period was most likely related, among other things, to the nuisance of dusting from unsurfaced roads and construction sites. The more than average air humidity in the autumn-winter period was also conducive to high air dust levels. High air humidity without rain but with fog formation may induce an increased concentration of suspended dust whose particles may serve as condensation nuclei for water molecules (Judy-Rezler and Toczko, 2016).

The work has proved a negative effect of Rh on the level of PM 10 concentration in the spring-summer period. With an increased content of water vapor in the atmosphere, the probability of wet deposition increases. This may cause self-cleaning of the atmosphere and a decrease in the level of dust concentration. On the other hand, in the case of atmospheric pressure positive correlations with PM10 were proved in three seasons of the year, except for summer. High pressure is recorded with radiative cooling of low atmosphere layers and often with formation of stable equilibrium in the atmosphere, including ground or elevated inversions.

Correlation coefficients between PM10 concentration and wind velocity assumed significantly negative values in all the examined seasons of the year. Long-lasting weather calm and low wind velocity are conducive to concentration of dust pollutants. Similar correlations between PM10 concentration and meteorological elements were observed by Kalbarczyk and Kalbarczyk (2008) in the town of Suwałki (north-east Poland) and by Krynicka and Drzeniecka-Osiadacz (2013) in Wrocław (south-west Poland).

The complex of meteorological elements most strongly determined PM10 concentration in autumn and next in winter; in all seasons of the year the strongest influence on dust pollution was exerted by $\mathrm{Ta}$ and $\mathrm{V}$. Meteorological elements in models describing air quality were also used by Rogalski et al. (2014), Majewski et al. (2015), Czernecki et al. (2017) and Stafoggia et al. (2017).

The PM10 content in air showed yearly, seasonal variability. PM10 concentration in winter was twice as high as in summer; however, the highest concentration of the 
analyzed pollutant in particular years was recorded in various months, both in January or February and in June or August. A similar time distribution of PM10 concentration throughout the year, which was probably an effect of variable activity of emission sources in particular months, was found by Bielec-Bąkowska et al. (2011), Jędruszkiewicz et al. (2017) and Czernecki et al. (2017).

The content of suspended dust underwent changes not only in subsequent years, but also displayed daily variability. The highest PM10 concentration in 2005-2016 was recorded in the cold season of the year, at late-evening hours; the lowest concentration was observed in summer months during the day. Daily variation of the content of suspended dust against the background of time distribution was also investigated by Tiwari et al. (2017).

Unfavorable aerosanitary conditions in winter were mostly recorded with easterly winds. In the eastern part of Poznan there are heat and power plants which, aside from causing air pollution, supply heat and electrical power mainly for the city. In particular years of the analyzed multi-year period increasingly warm summers, especially in the July-August period, and also winters could be observed. The monthly course of $\mathrm{Rh}$ was opposite compared to Ta; the highest average relative humidity of air was recorded in November and December. In Poznań, the highest air humidity was also recorded in November and December in 1951-1990 (Farat, 1996). At the measurement point wind was predominantly from the SW direction, and next the $\mathrm{W}$ direction; the directions $\mathrm{N}$ and NE were recorded least frequently; the average frequency of weather calm amounted to approx. 5.2\%. Compared to Farat's (1996) study, weather calm occurred with a similar frequency to 1951-1990. The remaining meteorological parameters (Ta, $\mathrm{Rh}, \mathrm{Pa}$ and $\mathrm{V}$ ) also did not deviate considerably from those in the research studies by Farat (1996) and Kalbarczyk (2010), which were conducted in 1966-2005. Such a high consistency of results is fairly surprising.

It occurred despite the fact that the second half of the 1990s was the period of introducing electrical sensors, marked by a greater accuracy, to weather monitoring. Also research on climate change indicates that in Poland there are ongoing changes in meteorological elements, confirmed by significant trends found during the years of the research.

\section{Conclusions}

The conducted research has shown dependence of daily PM10 concentration on meteorological conditions, mainly on air temperature variability and wind velocity. The strength and direction of the effect of the analyzed meteorological elements on PM10 concentration depended on the season of the year, the month and the time of day. The variability of dust concentration was explained by regression equations where meteorological elements were independent variables, with an accuracy from $13 \%$ (spring) to about $38 \%$ (autumn). The highest air dust levels were observed in winter, most frequently at late-evening hours and at night. In Poznań, increased air dust levels in winter occurred with low air temperatures, high relative humidity, low wind velocity, mainly from the E direction, and high atmospheric pressure. Meteorological elements which, as shown, significantly affect the level of PM10 concentration but also other air pollutants require constant observation due to changes in climatic conditions of Poland and the world. 


\section{REFERENCES}

[1] Adamek, A., Ziernicka-Wojtaszek, A. (2017): Variability of particulate matter PM10 concentration in Sosnowiec, Poland, depending on the type of atmospheric circulation. Applied Ecology and Environmental Research 15(4): 1803-1813. DOI: http://dx.doi.org/10.15666/aeer/1504_18031813.

[2] Badyda, A., Gayer, A., Czechowski, P. O., Majewski, G., Dąbrowiecki, P. (2016): Pulmonary function and incidence of selected respiratory diseases depending on the exposure to ambient PM10. - Int. Mol. Sci. 17(11): 1954. DOI: 10.3390/ijms17111954.

[3] Balakrishnaiah, G., Raghavendra Kumar, K., Suresh Kumar Reddy, B., Rama Gopal, K., Reddy, R. R., Reddy, L. S. S., Narasimhulu, K., Nazeer Ahammed, Y., Balanarayana, C., Krishna Moorthy, K., Suresh Babu, S. (2011): Characterization of PM, PM10 and PM2.5 mass concentrations at a tropical semi-arid station in Anantapur, India. - Indian J. Radio Space 40: 95-104.

[4] Bielec-Bąkowska, Z., Knozová, G., Leśniok, M., Matuszko, D., Piotrowicz, K. (2011): High suspended dust concentrations in Brno, Sosnowiec and Krakow (the year 2009 as an example). - Prace Geograficzne 126: 67-84.

[5] Bigi, A., Ghermandi, G. (2016): Trends and variability of atmospheric PM2.5 and PM102.5 concentration in the Po Valley, Italy. - Atmos. Chem. Phys. 16: 15777-15788. DOI: 10.5194/acp-16-15777-2016.

[6] Cesari, D., De Benedetto, G. E., Bonasoni, P., Busetto, M., Dinoi, A., Merico, E., Chirizzi, D., Cristofanelli, P., Donateo, A., Grasso, F. M., Marinoni, A., Pennetta, A., Contini, D. (2018): Seasonal variability of PM2.5 and PM10 composition and sources in an urban background site in Southern Italy. - Sci. Total Environ. 612: 202-213. DOI: 10.1016/j.scitotenv.2017.08.230.

[7] Chiang, Y. H., Yang, H. J., Chen, S. C., Hu, C. W., Tsai, C. T., Lai, D. J., Kuo, C. Y. (2017): Inhalation exposure of children to indoor PM10 and associated metals during river-dust episodes. - Air Qual. Atmos. Health 10: 381-388. https://doi.org/10.1007/s11869-016-0426-z.

[8] Chwil, S., Kozłowska-Strawska, J., Tkaczyk, P., Chwil, P., Matraszek, R. (2015): Assessment of air pollutants in an urban agglomeration in Poland made by the biomonitoring of trees. - J. Elem. 20(4): 813-826. DOI: 10.5601/jelem.2015.20.1.742.

[9] Ćwiek, K., Majewski, G. (2015): The influence of meteorological factors on the development of air pollutants concentration - Cracow case study. - Sci. Rev. Eng. Env. Sci. 67(2): 54-66 (in Polish).

[10] Czernecki, B., Półrolniczak, M., Kolendowicz, L., Marosz, M., Kendzierski, S., Pilguj, N. (2017): Influence of the atmospheric conditions on $\mathrm{PM}_{10}$ concentrations in Poznań, Poland. - J. Atmos. Chem. 74(1): 115-139. https://doi.org/10.1007/s10874-016-9345-5.

[11] D’Amato, G., Cecchi, L., D'amato, M., Liccardi, G. (2010): Urban air pollution and climate change as environmental risk factors of respiratory allergy: an update. - Journal of Investigational Allergology and Clinical Immunology 20(2): 95-102.

[12] Emmanouil, C., Drositi, E., Vasilatou, V., Diapouli, E., Krikonis, K., Eleftheriadis, K., Kungolos, A. (2017): Study on particulate matter air pollution, source origin, and human health risk based of PM10 metal content in Volos City, Greece. - Toxicol. Environ. Chem. 99(4): 691-709. doi.org/10.1080/02772248.2016.1242005.

[13] Farat, R. (1996): Climate of Poznan. - In: Kurek, L. (ed.) The Natural Environment of the City of Poznan. Vol. 1., Chapter 7, pp. 69-78. Wydział Ochrony Środowiska Urzędu Miasta Poznania, Poznan (in Polish).

[14] Flores, R. M., Kaya, N., Eşer, Ö., Saltan, Ş. (2017): The effect of mineral dust transport on PM10 concentrations and physical properties in Istanbul during 2007-2014. - Atmos. Res. 197: 342-355. DOI: 10.1016/j.atmosres.2017.07.009.

[15] Gładka, A., Zatoński, T. (2016): Impact of air pollution on respiratory diseases. Kosmos 65(4): 573-582. (in Polish). 
[16] Gliniak, M., Zuśka, Z., Miczyński, J. (2015): Evaluation of dust pollution level in Kraków agglomeration on the example of Al. A. Mickiewicza. - Logistyka 4: 8876-8881. (in Polish).

[17] Gustafsson, M., Forsberg, B., Orru, H., Åström, S., Tekie, H., Sjöberg, K. (2014): Quantification of Population Exposure to $\mathrm{NO}_{2}, \mathrm{PM} 2.5$ and PM10 and Estimated Health Impacts in Sweden 2010. Report. - Swedish Environmental Research Institute, Stockholm.

[18] Jędruszkiewicz, J., Czernecki, B., Marosz, M. (2017): The variability of PM10 and PM2.5 concentrations in selected Polish agglomerations: the role of meteorological conditions, 2006-2016. - Int. J. Environ. Health Res. 20: 1-22. DOI: 10.1080/09603123.2017.1379055.

[19] Judy-Rezler, K., Toczko, B. (eds.) (2016): Dust in the atmosphere. A compendium of knowledge about dust pollution in Poland. - Inspekcja Ochrony Środowiska. Biblioteka Monitoringu Środowiska (in Polish).

[20] Kalbarczyk, R. (2010): Unfavourable thermal conditions of air at the turn of the 20th and 21st centuries reducing crop productivity of pickling cucumber (Cucumis sativus L.) in Poland. - Span. J. Agric. Res. 8(4): 1163-1173. DOI: 10.5424/sjar/2010084-1406.

[21] Kalbarczyk, R., Kalbarczyk, E. (2008): Concentration of gas and particulate air pollutants in Suwałki analysed in relation to meteorological conditions. - Pol. J. Natur. Sci. 23: 134151.

[22] Kiesewetter, G., Borken-Kleefeld, J., Schöpp, W., Heyes, C., Bertok, I., Thunis, P., Bessagnet, B., Terrenoire, E., Amann, M. (2013): Modelling compliance with $\mathrm{NO}_{2}$ and PM10 air quality limit values in the GAINS model. - TSAP Report \#9, Version 1.0.

[23] Krynicka, J., Drzeniecka-Osiadacz, A. (2013): Analysis of variability in PM10 concentration in the Wrocław agglomeration. - Pol. J. Environ. Stud. 22: 1091-1099.

[24] Li, L., Wu, A. H., Cheng, I., Chen, J. C., Wu, J. (2017): Spatiotemporal estimation of historical PM2.5 concentrations using PM10, meteorological variables, and spatial effect. - Atmos. Environ. 166: 182-191. https://doi.org/10.1016/j.atmosenv.2017.07.023.

[25] Majewski, G., Rogula-Kozłowska, W., Czechowski, P. O., Badyda, A., Brandyk, A. (2015): The impact of selected parameters on visibility: first results from a long-term campaign in Warsaw, Poland. - Atmosphere-Basel 6: 1154-1174. DOI: 10.3390/atmos6081154.

[26] Maji, K. J., Arora, M., Dikshit, A. K. (2017): Burden of disease attributed to ambient PM2.5 and PM10 exposure in 190 cities in China. - Environ. Sci. Pollut. Res. 24: 1155911572. DOI: 10.1007/s11356-017-8575-7.

[27] Mok, K. M., Miranda, A. I., Yuen, K. V., Hoi, K. I., Monteiro, A, Ribeiro, I. (2017): Selection of bias correction models for improving the daily PM10 forecasts of WRFEURAD in Porto, Portugal. - Atmos. Pollut. Res. 8: 628-639. https://doi.org/10.1016 /j.apr.2016.12.010.

[28] NIK's Report (2014): Protection of the air against pollution. Information about control results. - Raport NIK 2014. nr ewid. 177/2014/P/14/086/LKR (in Polish).

[29] Pannullo, F., Lee, D., Neal, L., Dalvi, M., Agnew, P., O’Connor, F. M., Mukhopadhyay, S., Sahu, S., Sarran, C. (2017): Quantifying the impact of current and future concentrations of air pollutants on respiratory disease risk in England. - Environ. Health 16: 29. https://doi.org/10.1186/s12940-017-0237-1.

[30] Redington, A. L., Witham, C. S., Hort, M. C. (2016): Source apportionment of speciated PM10 in the United Kingdom in 2008: Episodes and annual averages. - Atmos. Environ. 145: 251-263. https://doi.org/10.1016/j.atmosenv.2016.09.047.

[31] Resolution no. 3056/2016 of Great-Polish Voivodship of 29 Dec. (2016): Resolution no. 3056/2016 of Great-Polish Voivodship Administration of Dec. 29, 2016 accepting the motion of the Regional Convention on the program for air quality protection in the GreatPolish area (in the range of PM10 dust, PM2,5 and B(a)P). [Uchwała nr 3056/2016 Zarządu Województwa Wielkopolskiego z dnia 29 grudnia 2016 roku w sprawie 
przyjęcia projektu uchwały Sejmiku Województwa Wielkopolskiego w sprawie określenia programu ochrony powietrza dla strefy wielkopolskiej (w zakresie pyłu PM10, PM2,5 oraz B(a)P)] (in Polish).

[32] Richter, D., Williams, W. P. (1998): Assessment and Management of Urban Air Quality in Europe. EEA monograph no. 5. - European Environment Agency, Copenhagen.

[33] Rogalski, L., Smoczyński, L., Krzebietke, S., Lenart, L., Mackiewicz-Walec, E. (2014): Changes in sulphur dioxide concentrations in the atmospheric air assessed during shortterm measurements in the vicinity of Olsztyn, Poland. - J. Elem. 735-748. DOI: 10.5601/jelem.2014.19.2.634.

[34] Segersson, D., Eneroth, K., Gidhagen, L., Johansson, C., Omstedt, G., Nylén, A. E., Forsberg, B. (2017): Health impact of PM10, PM2.5 and black carbon exposure due to different source sectors in Stockholm, Gothenburg and Umea, Sweden. - Int. J. Environ. Res. Public Health 14: 742. DOI: 10.3390/ijerph14070742.

[35] Sosa, B. S., Porta, A., Colman Lerner, J. E., Banda Noriega, R. B., Massolo, L. (2017): Human health risk due to variations in PM10-PM2.5 and associated PAHs levels. Atmos. Environ. 160: 27-35. https://doi.org/10.1016/j.atmosenv.2017.04.004.

[36] Stafoggia, M, Schwartz, J., Badaloni, Ch., Bellander, T., Alessandrini, E., Cattani, G., de' Donato, F., Gaeta, A., Leone, G., Lyapustin, A., Sorek-Hamer, M., de Hoogh, K., Di, Q., Forastiere, F., Kloog, I. (2017): Estimation of daily PM10 concentrations in Italy (20062012) using finely resolved satellite data, land use variables and meteorology. - Environ. Int. 99: 234-244. https://doi.org/10.1016/j.envint.2016.11.024.

[37] Tasić, V., Kovačević, R., Maluckov, B., Apostolovski-Trujić, T., Matić, B., Cocić, M., Steharnik, M. (2017): The content of as and heavy metals in TSP and PM10 near copper smelter in Bor, Serbia. - Water Air Soil Pollut. 228: 230. https://doi.org/10.1007/s11270017-3393-6.

[38] Tiwari, S., Dumka, U. C., Gautam, A. S., Kaskaoutis, D. G., Srivastava, A. K., Bisht, D. S., Chakrabarty, R. K., Sumlin, B. J., Solmon, F. (2017): Assessment of PM2.5 and PM10 over Guwahati in Brahmaputra River Valley: Temporal evolution, source apportionment and meteorological dependence. - Atmos. Pollut. Res. 8: 13-28. https://doi.org/10.1016/j.apr.2016.07.008.

[39] World Health Organization (2013): Review of Evidence on Health Aspects of Air Pollution. REVIHAAP Project. - WHO Regional Office for Europe, Copenhagen, Denmark.

[40] Yang, W.Y, Zhang, Z.Y, Thijs, L., Bijnens, E. M., Janssen, B. G., Vanpoucke, C., Lefebvre, W., Cauwenberghs, N., Wei, F. F., Luttun, A., Verhamme, P., Van Hecke, E., Kuznetsova, T., D’hooge, J., Nawrot, T. S., Staessen, J. A. (2017): Left ventricular function in relation to chronic residential air pollution in a general population. - Eur. J. Prev. Cardiol. 24(13): 1416-1428. https://doi.org/10.1177/2047487317715109. 